\title{
Identification and Elucidation of the Designing and Operational Issues of Trickling Filter Systems for Wastewater Treatment
}

\author{
Imran Ali ${ }^{1}$, Zahid M. Khan ${ }^{2}$, Changsheng Peng ${ }^{1}$, Iffat Naz ${ }^{3}$, Muhammad Sultan ${ }^{2 *}$, \\ Mohsin Ali ${ }^{4}$, Muhammad H. Mahmood ${ }^{2}$, Yasir Niaz \\ ${ }^{1}$ College of Environmental Science and Engineering, Ocean University of China, Qingdao 266100, China \\ ${ }^{2}$ Department of Agricultural Engineering, Bahauddin Zakariya University, Bosan Road, Multan, Pakistan \\ ${ }^{3}$ Department of Biology, Qassim University, Buraidah 51452, Kingdom of Saudi Arabia \\ ${ }^{4}$ Department of Environmental Engineering, Middle East Technical University, Ankara 0600, Turkey \\ ${ }^{5}$ Department of Environmental Management and Policy, Balochistan University of Information Technology, \\ Engineering and Management Sciences, Quetta 87300, Pakistan
}

Received: 26 March 2017

Accepted: 22 April 2017

\begin{abstract}
Water pollution has become a major environmental concern for public and environmental health in developing countries. Water resources are being contaminated mainly due to mixing of domestic, municipal, and industrial wastewaters. The wastewater management and treatment situation is deplorable mainly because of financial constraints, the unavailability of technically trained human resources, and electricity shortages. Moreover, there is a challenge for the scientific community and wastewater management experts to explore cost-effective, simple, reliable, and efficient wastewater treatment systems. Therefore, the present review highlights the option of trickling filter (TF) systems for wastewater treatment in developing countries like Pakistan, India, Bangladesh, and African regions, etc. In addition, the solutions to the operational/performance issues of the TF system are explored and discussed in greater detail for designing/construction of new TF systems and retrofitting the existing TFs.
\end{abstract}

Keywords: wastewater treatment, trickling filter systems, operational issues, performance issues

\section{Introduction}

Water pollution is one of the main impediments to public health in developing countries like Pakistan, India, Bangladesh, and African regions etc. [1-2]. Wastewater generation is increasing day by day due to the rapid

*e-mail: muhammadsultan@bzu.edu.pk development in agricultural and industrial activities [3]. The level of water pollution is also increasing at a fast pace due to the mixing of sewage and industrial effluent into the residential water supply systems in big cities of the country [4]. The brunt of the adverse impacts of water pollution is faced by humans, animals, aquatic biota, agriculture, and so forth [5-6]. An estimated 7.5708 $\times 109 \mathrm{~L}$ of wastewater is being disposed of into water-receiving environments every day only in the case of Pakistan [7-10]. The main water pollutants present in wastewater are pathogens (i.e., 
bacteria, protozoas, and viruses), organic compounds (i.e., oil and pesticides), inorganic compounds (i.e, toxic metals and acids salts), anions and cations from industrial effluent (i.e., nitrates, sulphates, phosphate, $\mathrm{Ca}^{+2}, \mathrm{Mg}^{+2}$, and $\mathrm{F}^{-}$), and water-soluble radioactive substances, which mainly damage water quality [1, 11-12].

About $6-8 \%$ of the generated wastewater receives treatment before disposal into the receiving water environment, but this figure is based on the assumption that all the treatment systems operate at their full designed capacity, which is not true [1-3]. Further, developing economies like Pakistan and Bangladesh are also facing an energy crisis and electricity fluctuations in the shape of load shedding. It has been observed that typically $30-50 \%$ of the operating cost of a conventional wastewater treatment plant belongs to energy consumption. Moreover, $50 \%$ is utilized for aeration during biological wastewater treatment, and this is the highest percentage compared to other unit operations and processes [1314]. The key consideration and hindrance in selection of a suitable treatment system is the cost, energy, trained human resources, system compatibility, and operational complications [15]. The right choice of an appropriate and workable technology is very important because of the

Table 1. Studies conducted for wastewater treatment: a case study for Pakistan.

\begin{tabular}{|c|c|c|c|}
\hline Treatment system & Wastewater type/matrix & Measured parameters and pollutant removed & Reference \\
\hline Phytoremediation & $\begin{array}{l}\text { Aqueous solution of heavy } \\
\text { metals }\end{array}$ & Heavy Metals & {$[18]$} \\
\hline $\begin{array}{l}\text { Endophyte-Assisted Floating } \\
\text { Treatment Wetlands }\end{array}$ & $\begin{array}{c}\text { Municipal } \\
\text { wastewater }\end{array}$ & $\mathrm{COD}, \mathrm{BOD}_{5}, \mathrm{TN}, \mathrm{PO}_{4}^{3-}$ & {$[19]$} \\
\hline Membrane Bioreactor & Wastewater & $\begin{array}{l}\text { COD, MLSS, MLVSS, ammonium nitrogen, } \\
\text { phosphate-phosphorus, and TOC }\end{array}$ & {$[20]$} \\
\hline $\begin{array}{c}\text { Bioremediation (Constructed } \\
\text { Wetlands) }\end{array}$ & Municipal wastewater & $\begin{array}{c}\mathrm{BOD}_{5}, \mathrm{COD} \text {, and nutrients (nitrogen and } \\
\text { phosphorus) }\end{array}$ & {$[21]$} \\
\hline Constructed Wetlands & Domestic wastewater & $\begin{array}{l}\text { TSS, TDS, } \mathrm{SO}_{4}^{-2}, \mathrm{PO}_{4}^{-3}, \mathrm{NO}_{3}, \mathrm{NO}_{2} \text { bacterial } \\
\text { counts and fecal pathogens }\end{array}$ & {$[22]$} \\
\hline Trickling Biofilter System & Municipal wastewater & $\begin{array}{c}\text { Ammonium nitrogen, } \mathrm{BOD}_{5}, \mathrm{COD} \text {, and } \\
\text { pathogen }\end{array}$ & {$[23]$} \\
\hline Bio-Sorption & Synthetic wastewater & $\mathrm{NH}_{4}^{+}$ & {$[24]$} \\
\hline $\begin{array}{c}\text { Anaerobic Reactor and Fenton's } \\
\text { Process }\end{array}$ & Textile wastewater & Color, COD, and turbidity & {$[25]$} \\
\hline Constructed Wetlands & Industrial wastewater & $\begin{array}{l}\text { EC, turbidity, COD, TSS, TDS, TS, nitrates, } \\
\text { ammonia, phosphates, heavy metals (i.e., } \mathrm{Cd} \text {, } \\
\mathrm{Ni}, \mathrm{Hg} \text {, and } \mathrm{Pb} \text { ) }\end{array}$ & {$[26]$} \\
\hline Bio-Sorption & Textile wastewater & COD, TDS, TSS, and color & {$[27]$} \\
\hline Bio-Remediation & Textile wastewater. & BOD, COD, TOC, and cytotoxicity & {$[28]$} \\
\hline Advanced Oxidation Processes & Municipal wastewater & $\begin{array}{l}\text { BOD, COD, turbidity, conductivity, } \mathrm{pH} \text {, and } \\
\text { fecal coliform }\end{array}$ & {$[29]$} \\
\hline $\begin{array}{l}\text { Fixed Biomass and Sand Column } \\
\text { Reactor } \\
\end{array}$ & Municipal wastewater & $\begin{array}{l}\text { Odor, alkalinity, } \mathrm{pH} \text {, turbidity, } \mathrm{BOD}_{5}, \mathrm{COD} \text {, } \\
\text { TDS, TSS, } \mathrm{EC}, \mathrm{PO}_{4}, \mathrm{SO}_{4}, \mathrm{NO}_{3}, \mathrm{NO}_{2} \text {, and DO }\end{array}$ & {$[30]$} \\
\hline Membrane Bioreactor & Synthetic wastewater & Nutrients & {$[31]$} \\
\hline $\begin{array}{l}\text { Hybrid Constructed Wetland } \\
\text { (HCW) }\end{array}$ & Domestic wastewater & $\begin{array}{c}\mathrm{NO}_{3}, \mathrm{NO}_{2}, \mathrm{BOD}_{5}, \mathrm{COD}, \mathrm{SO}_{4}, \mathrm{PO}_{4} \text {, and } \\
\text { pathogenic }\end{array}$ & {$[32]$} \\
\hline Fixed Biofilm Reactor & Municipal wastewater & $\begin{array}{l}\text { Bacterial count (Escheria coli and feacal } \\
\text { coliforms), } \mathrm{COD}, \mathrm{BOD}, \mathrm{pH}, \mathrm{NO}^{-2}, \mathrm{NO}^{-3} \text {, } \\
\qquad \mathrm{PO}_{4}^{-3}, \mathrm{SO}_{3}^{-2}\end{array}$ & {$[33]$} \\
\hline $\begin{array}{c}\text { Integrated Wastewater Treatment } \\
\text { System (i.e., Aeration, Coagulation } \\
\text { and Advance Oxidation Processes) }\end{array}$ & Carwash industry wastewater & $\begin{array}{c}\text { COD, TDS, turbidity, } \mathrm{DO}, \mathrm{pH} \text {, and oil } \\
\text { contents }\end{array}$ & {$[34]$} \\
\hline Constructed Wetland & Industrial wastewater & $\mathrm{Ni}, \mathrm{Cd}, \mathrm{Pb}, \mathrm{Fe}, \mathrm{Cr}$, and $\mathrm{Cu}$ & {$[35$} \\
\hline Constructed Wetland & $\begin{array}{l}\text { Industrial wastewater (oil } \\
\text { refinery effluents) }\end{array}$ & $\begin{array}{l}\text { TSS, COD, BOD, heavy metals, i.e. } \mathrm{Zn}^{+2} \text {, } \\
\mathrm{Cu}^{+2} \text {, and } \mathrm{Fe}^{+2}\end{array}$ & {$[36]$} \\
\hline $\begin{array}{l}\text { Waste Stabilization Ponds (WSP) or } \\
\text { Lagoons }\end{array}$ & Domestic wastewater & $\begin{array}{l}\mathrm{BOD}_{5}, \mathrm{COD}, \mathrm{NH}_{3}-\mathrm{N} \text {, total kjeldahl nitrogen } \\
(\mathrm{TKN}), \mathrm{PO}_{4}-\mathrm{P} \text {, and coliforms }\end{array}$ & {$[37]$} \\
\hline
\end{tabular}


economic limitations and consequences of the decision [16]. Unnecessarily costly treatment will divert scarce resources away from other development projects [17]. In this regard, many local research groups are actively involved in research related to the selection of wastewater treatment systems for developing countries such as constructed wetlands, fixed-film bio reactors, membrane bio reactors, bio sorption-based processes, anaerobic process-based treatment, and advanced oxidation processes, but the level of research is too low and just focuses on the removal of conventional pollutants. It was also observed that the adopted technology is just suitable for lab-scale experiments and these technologies demand extensive research for practical applications. A short summary of these experimental works is discussed in greater detail in Table 1.

\section{Trickling Filter System Design, Operation, and Application}

Keeping in mind these facts, it is fairly difficult to propose a suitable wastewater treatment system for developing countries because of financial constraints, lack of technically trained staff, and electricity shortages. Therefore, to the best of our knowledge this is the first review paper mainly focusing on the technical aspects of Trickling filters (TFs), their suitability, and applications in water and wastewater treatment, and the identification of operational and performance problems with their corresponding solutions are discussed in light of available published literature. However, the success rate of the TF system is poor because of unskilled operating staff, unawareness about process philosophy, and/or inadequate aeration of biological units owing to the low availability of electricity [1]. Therefore, first of all it is important to identify the basic complications regarding existing wastewater treatment systems and to then explore the possible solution approaches, although limited evidence is present in the published literature (TF systems) and their subsequent solutions. Furthermore, this is the very first time anyone has identified and summarized operational and performance issues of TFs with subsequent solutions because the success of a wastewater treatment plant not only depends upon technical expertise and planning, but also on skilled operation.

TFs are well known in the field of biological wastewater treatment systems because the microorganisms play a key role in minimizing pollutant strength. Microbial communities have natural physiological and metabolic capabilities to remove a wide range of pollutants [14]. Microorganisms have a natural ability to stick to wet faces, multiply, and embed themselves in a slimy environment composed of the extracellular polymeric substances (EPSs) they produce, forming a biofilm [38]. Mostly high-specific surface area is available in attached growth systems, which are essential for healthy growth of biofilm. Importantly, a TF system has the ability to retain higher biomass with higher metabolic capacity than suspended growth treatment systems when operated under the same conditions [13]. Now TFs are getting attention rather than other attached growth systems because of their low operating and maintenance requirements and especially their capability to treat and handle shock organic loads. Furthermore, the TFs have been designed using different kinds of biofilm packing materials to improve treatment efficiency as listed in Tables 2 and 3. System performance depends mainly on the health and growth of the biofilm onto packing material.

After the development of the biofilm layer, as the influent flows over the slime layer of 0.1-0.2 mm thickness, organic pollutants such as biochemical oxygen demand $\left(\mathrm{BOD}_{5}\right)$, chemical oxygen demand (COD), ammonia, and dissolved oxygen (DO) disperse into the slime layer where they will degrade organic matters with the help of microorganisms. Mass transport and biotransformation are the two main processes for the removal of pollutants in TFs [14, 39]. Anaerobic condition is maintained at the bottom of the biofilm layer, as the thickness of the slime layer increases. The biofilm layer loses its ability to adhere to the media because of the absence of the extra organic source available for the attachment of the cell carbon. The incoming wastewater then washes down the biofilm from the support medium and a new slime layer starts to develop [40]. The attached growth systems, such as TFs, are comparatively superior to other biological wastewater treatment systems, as it is not an electricityintensive process, is technically less complicated, and is cost effective [41].

TFs are relatively simple and reliable, and require less space, making it suitable in areas where large strips

Table 2. Potentials of trickling filter systems for water purification.

\begin{tabular}{|c|c|c|c|}
\hline Filter media & $\begin{array}{c}\text { Pollutant } \\
\text { removed }\end{array}$ & Study area & Reference \\
\hline Stone & Ammonia & Greece & {$[46]$} \\
\hline Gravel & Iron & Greece & {$[47]$} \\
\hline Gravel & $\begin{array}{c}\mathrm{NH}_{3}, \mathrm{Fe}, \text { and } \\
\mathrm{Mn}\end{array}$ & Greece & {$[48]$} \\
\hline Gravel & Chromium(VI) & Greece & {$[49]$} \\
\hline Silicic gravel & Iron & Greece & {$[50]$} \\
\hline $\begin{array}{c}\text { Hollow plastic } \\
\text { tubes and } \\
\text { calcitic gravel }\end{array}$ & Cr(VI) & Greece & {$[51]$} \\
\hline $\begin{array}{c}\text { Silicic gravel } \\
\text { Polypropylene } \\
\text { Plastic }\end{array}$ & Manganese & Greece & {$[52]$} \\
\hline Gravel & Nitrate & Greece & {$[54]$} \\
\hline Gravel & Ammonia & Greece & {$[55]$} \\
\hline $\begin{array}{c}\text { Gravel } \\
\text { Aron, and } \\
\text { manganese }\end{array}$ & Greece & {$[56]$} \\
\hline
\end{tabular}


Table 3. Potentials of trickling filter systems for wastewater treatment.

\begin{tabular}{|c|c|c|c|c|}
\hline Wastewater type/matrix & Filter media used & Pollutant removed & Study area & Ref. \\
\hline Municipal wastewater & $\begin{array}{l}\text { Mixed-media (granite, } \\
\text { clinker blast furnace slag, } \\
\text { and RC plastic) }\end{array}$ & $\begin{array}{l}\text { BOD, SS, TN, Ammonia, } \mathrm{pH} \text {, } \\
\text { conductivity and turbidity, synthetic } \\
\text { detergent, total phosphate, chloride, } \\
\text { and heavy metals }\end{array}$ & Cardiff, Wales & {$[57]$} \\
\hline Municipal wastewater & Sand & $\begin{array}{c}\text { COD, microorganisms and } \\
\text { pharmaceuticals (e.g., Ibuprofen or } \\
\text { Naproxen) }\end{array}$ & Germany & {$[58]$} \\
\hline Dye wastewater & Silica gravel & COD & Greece & [59] \\
\hline Synthetic wastewater & NG & Cooper $(\mathrm{Cu})$ & UK & [60] \\
\hline Textile Wastewater & Polyurethane foam (PUF) & Color, dyes, and TOC & Czech Republic & [61] \\
\hline Domestic Wastewater & Coal cinder & $\mathrm{COD}, \mathrm{NH}_{4}^{+}, \mathrm{TP}$, and SS & China & {$[62]$} \\
\hline Domestic Wastewater & Polyurethane foam pores & COD & China & [63] \\
\hline Mine water & Plastic & Iron & UK & [64] \\
\hline Industrial wastewater & Mineral (Synthetic prepared) & Phenol & Greece & {$[65]$} \\
\hline Industrial wastewater & Mineral (Synthetic prepared) & Phenol & Greece & [66] \\
\hline Synthetic wastewater & Porous medium & $\begin{array}{l}\text { Toluene, o-cresol, phenol, } \\
\text { 1,2,3-trimethylbenzene, and } \\
\text { naphthalene }\end{array}$ & Greece & [67] \\
\hline Municipal wastewater & Gravel & $\mathrm{BOD}$ and nitrogen & USA & [68] \\
\hline Synthetic wastewater & Plastic & Hexavalent chromium $(\mathrm{Cr}(\mathrm{VI}))$ & Greece & [69] \\
\hline Municipal wastewater & Corrugated plastic sheet & $\begin{array}{c}\mathrm{TSS}, \mathrm{BOD}_{5}, \mathrm{COD}, \mathrm{TKN}, \mathrm{NO}_{3}-\mathrm{N}, \\
\text { and TP }\end{array}$ & France & [41] \\
\hline Domestic sewage & Stones & $\begin{array}{c}\mathrm{pH} \text {, odor, turbidity, alkalinity, } \mathrm{COD} \text {, } \\
\mathrm{BOD}_{5}, \mathrm{TDS}, \mathrm{TSS}, \mathrm{EC}, \mathrm{PO}_{4}, \mathrm{SO}_{2}^{-4}, \\
\mathrm{NO}^{-2}, \mathrm{NO}^{-3} \text {, and bacterial count }\end{array}$ & Pakistan & [70] \\
\hline Synthetic wastewater & $\begin{array}{l}\text { Crushed leca and plastic } \\
\text { media }\end{array}$ & Ammonia nitrogen & Norway & [71] \\
\hline $\begin{array}{c}\text { Swine } \\
\text { lagoon wastewater }\end{array}$ & $\begin{array}{l}\text { Plastic (Bioballs and } \\
\text { recycled soda six-pack rings) }\end{array}$ & $\mathrm{BOD}_{5}, \mathrm{COD}, \mathrm{NH}_{3}-\mathrm{N}$, and TKN & USA & [72] \\
\hline Synthetic wastewater & $\begin{array}{c}\text { Plastic media and calcitic } \\
\text { gravel }\end{array}$ & $\mathrm{Cr}(\mathrm{VI})$ & Greece & {$[51]$} \\
\hline Municipal wastewater & Oyster shell and plastic balls & $\mathrm{COD}, \mathrm{NH}_{3}-\mathrm{N}$, and $\mathrm{TP}$ & China & [73] \\
\hline Combined wastewater & Oyster shell & $\mathrm{COD}, \mathrm{BOD}, \mathrm{NH}_{3}-\mathrm{N}, \mathrm{TP}$, and TSS & China & [74] \\
\hline Domestic sewage & Luffa cyllindrica & $\begin{array}{c}\mathrm{BOD}_{5,20}, \mathrm{COD}, \mathrm{SS}, \text { and settleable } \\
\text { solids }\end{array}$ & Brazil & [75] \\
\hline Synthetic wastewater & Geotextile & $\begin{array}{l}\text { Organic nitrogen and phosphorus } \\
\text { COD, }\end{array}$ & Canada & [76] \\
\hline Synthetic wastewater & Nylon pot scrubber & Ammonium & India & [77] \\
\hline Domestic wastewater & Plastic balls & $\begin{array}{l}\mathrm{COD}, \mathrm{BOD}_{5}, \mathrm{TSS} \text {, turbidity, } \mathrm{NO}_{3}, \\
\mathrm{NO}_{2}, \mathrm{SO}_{4}, \mathrm{PO}_{4} \text {, and pathogenic } \\
\text { indicator microbes }\end{array}$ & Pakistan & [78] \\
\hline Domestic wastewater & Tire derived rubber (TDR) & $\begin{array}{l}\mathrm{BOD}, \mathrm{COD}, \text { pathogen indicators, } \\
\mathrm{pH}, \mathrm{NO}^{2-}, \mathrm{NO}^{3-}, \mathrm{PO}_{4}^{3-} \text {, and } \mathrm{SO}_{3}^{2-}\end{array}$ & Pakistan & [33] \\
\hline Municipal wastewater & Stones & $\left.\mathrm{BOD}_{5}, \mathrm{COD}, \mathrm{NH}_{4}-\mathrm{N}\right)$, and pathogen & Pakistan & [79] \\
\hline Municipal wastewater & $\begin{array}{l}\text { Rubber, polystyrene, } \\
\text { Plastic, and stone }\end{array}$ & $\begin{array}{l}\text { Chemical oxygen demand and BOD, } \\
\text { faecal coliforms }\end{array}$ & Pakistan & [23] \\
\hline Municipal wastewater & Stones & $\begin{array}{l}\text { Odor, alkalinity, } \mathrm{pH}, \text { turbidity, } \\
\mathrm{BOD} 5, \mathrm{COD}, \mathrm{TDS}, \mathrm{TSS}, \mathrm{EC}, \mathrm{PO}_{4}^{3-} \\
\mathrm{SO}_{3}^{2}, \mathrm{NO}^{2-}, \mathrm{NO}^{3-} \text {, and pathogens }\end{array}$ & Pakistan & {$[72]$} \\
\hline
\end{tabular}


Table 3. Continued.

\begin{tabular}{|c|c|c|c|c|}
\hline Synthetic wastewater & Ceramic particles & Methyl acrylate & China & [80] \\
\hline Municipal wastewater & Stones & $\begin{array}{l}\text { Di-(2-ethylhexyl) phthalate and } \\
\text { diethyl phthalate }\end{array}$ & UK & [81] \\
\hline Synthetic wastewater & Sponge & COD and TN & UK & {$[82]$} \\
\hline Industrial wastewater & Ceramic foams & Phenol & Spain & [83] \\
\hline Textile wastewater & TM foam & Organic dyes & Czech Republic & [84] \\
\hline Industrial wastewater & Ceramic material & $\begin{array}{l}\text { COD and ammonia nitrogen } \\
(\mathrm{NH} 4+-\mathrm{N})\end{array}$ & China & [85] \\
\hline Synthetic Wastewater & PORAVER particles & Phenol and TOC & Portugal & [86] \\
\hline $\begin{array}{l}\text { Synthetic Gold mill } \\
\text { wastewater }\end{array}$ & $\begin{array}{l}\text { Plastic rings of } \\
\text { polypropylene }\end{array}$ & $\begin{array}{l}\text { COD, copper, thiocyanate, free } \\
\text { cyanide, iron, and zinc }\end{array}$ & Brazil & [87] \\
\hline Landfill leachate & Polypropylene plastic media & $\begin{array}{l}\text { Ammonium and organic carbon } \\
\text { (TOC) }\end{array}$ & UK & [88] \\
\hline Synthetic wastewater & Sponge-bed & $\mathrm{NH} 4+-\mathrm{N}$ and total nitrogen & Netherlands & [89] \\
\hline Synthetic wastewater & Biochar chips & $\mathrm{NH} 4+-\mathrm{N}$ and TP/NOx-N & China & {$[44]$} \\
\hline Domestic wastewater & $\begin{array}{l}\text { Sponge, zeolite and } \\
\text { ceramsite }\end{array}$ & COD and ammonia & China & [90] \\
\hline Synthetic wastewater & Sponge-bed & Total nitrogen & Netherlands & [91] \\
\hline Municipal wastewater & Corrugated plastic sheet & $\begin{array}{c}\mathrm{TSS}^{\mathrm{BOD}}{ }_{5}, \mathrm{COD}, \mathrm{TKN}, \mathrm{NO}-\mathrm{N}, \\
\text { and TP }\end{array}$ & France & [41] \\
\hline Municipal wastewater & Plastic media & Phosphate & France & [92] \\
\hline Synthetic wastewater & Lantec HD Q-PAC® & Organic matters & Belgium & [93] \\
\hline Real Wastewater & $\begin{array}{l}\text { Agricultural Waste (Maize } \\
\text { cobs) }\end{array}$ & $\begin{array}{c}\mathrm{BOD}_{5}, \mathrm{COD}, \mathrm{TSS}, \mathrm{TDS}, \text { turbidity, } \\
\text { and color }\end{array}$ & Pakistan & [94] \\
\hline
\end{tabular}

of land are not vacant for treatment systems. It is also an appropriate wastewater treatment option for small- to medium-sized communities. It takes less time to minimize $\mathrm{BOD}_{5}$ from wastewater with low power requirements. TF system design advantages compare to other secondary wastewater treatment systems can be summarized as TFs require less operational energy in the shape of energyconsuming aeration blowers. The only energy consumed is when we use an electrical device for the rotation of distributor arms. Natural ventilation is historically the primary means of providing airflow, but somehow we use low-pressure fans for requirements of controlled airflow. The operational and maintenance cost of TFs is $47 \%$ less than compared to an activated sludge system. The TF system has a low mechanical complexity compared with the activated sludge system because it has simply a rotating arm for wastewater distribution in trickle form. TFs use natural ventilation while an air diffuser is used in an activated sludge system for aeration purposes. TFs are less reactor resilient for power failure and shock organic loads because TF systems have the ability to handle and recover from shock loads. However, in an activated sludge system the shock load increases the retention time of treatment systems [13].

TF systems are known as attached growth biological systems, where the wastewater contact with bacteriological communities is attached to the surface of the filter media. The influent is distributed over the bed of filter media. After the development of synthetic media used in place of stone, the term "biological tower" is introduced instead of TFs. Primary clarification is necessary before rock TFs, helping settle most heavy particles, which can clog the filter. In some installations, a wire-mesh screen is placed over the top of the plastic packing to collect debris that can be vacuumed off periodically [42]. The influent trickling over the filter media produces biofilm that covers the filter media. This biofilm consists primarily of bacteria, protozoa, algae, and fungi (about 0.1 to $0.2 \mathrm{~mm}$ thick) $[13-14,33]$. As the wastewater flows over the biofilm, organic matters are degraded into carbon dioxide and water due to the metabolic activity of the microbes. In the bottom of the filter, the nitrifying bacteria are present for nitrification. The fungi present may also be responsible for minimizing pollutants, but this will work only at low $\mathrm{pH}$. The job of protozoa is to feed the biological films and, as a result, effluent turbidity decreases and the biofilms are maintained at a higher growth state. Sloughing is the phenomenon of losing or breaking the biofilm layer due to endogenous respiration conditions of the bacteria to lose their power to stick to the filter media. Then the incoming flow will slough off the biomass from filter media, and a new biofilm layer will start to develop. This phenomenon 


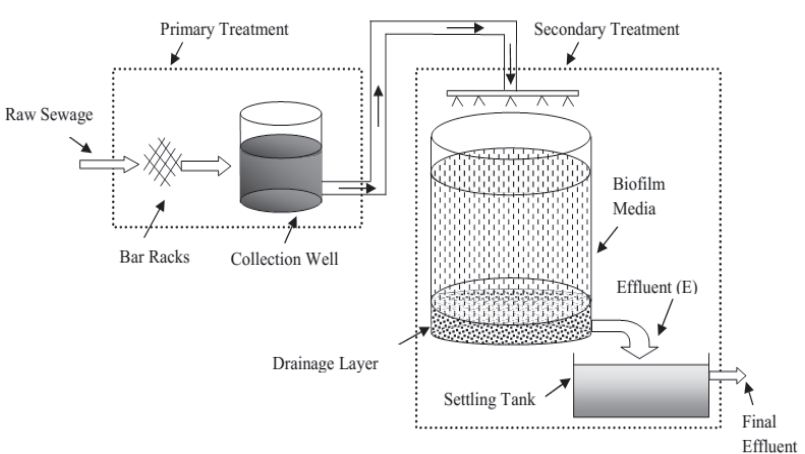

Fig. 1. Schematic illustration of trickling filter wastewater treatment system.

is mainly a function of incoming organic and hydraulic loading [13, 43].

The major components of the typical TFs are a rotary distributor, under-drain system, and filter media as shown in Fig. 1. The influent wastewater is pumped up a vertical riser to a rotary distributor for spreading uniformly over the filter media surface. Rotary arms are driven by the reaction from the wastewater flowing out of the distributor nozzles. Bed under-drains carry away the effluent and permit air circulation. The floor and under-drain block slope to a central or peripheral drainage channel at a $1-5 \%$ grade. Ventilation risers and the effluent channel are designed to allow free opening of air. In some installations, the under-drain blocks empty into a channel between double exterior walls to allow improved aeration and access for flushing of under-drains. The most common media in existing filters are crushed rock, slag, or field stone that are durable, insoluble, and resistant to spalling. The size range preferred for stone media is 3-5 inches in diameter. Although smaller stone provides greater surface area for biological growth, the voids tend to plug and limit passage of liquid and air [13,38]. Distribution systems are provided for spray of wastewater in trickle form into media surface. Nozzles are arranged unevenly so that greater flow per unit of length is achieved near the periphery of the filter than at the center. Head loss through the distributor is in the range of 0.6 to $1.5 \mathrm{~m}[13,44]$.

Typically, TFs achieve $85-90 \%$ BOD removal efficiency and $80-85 \%$ COD removal efficiency. Such systems have high process stability, low sludge processing requirement, and low hydraulic retention time (HRT) as compared to activated sludge and rotating biological contactors [45]. Its low sludge production is related to a primary settling tank for influent collection before going toward a filter. A new revelation has come in the form of TF performance after using plastic filter media instead of rock or stones because plastic filter media are different in shape and arrangement and have good properties of aeration and are more durable. Having reviewed the published literature related to TF performance, a brief summary of its application in water purification and wastewater treatment is discussed in Tables 2 and 3. Having discussed the advantages of the TFs, it is also a fact that like any other treatment system, it has its own limitations, problems, and operational troubles, and if not dealt with properly it will adversely affect the treatment performance. It is important to identify the causes of frequent problems encountered during the operation of TFs and to explore their solutions for smooth and satisfactory operation.

\section{Trickling Filter Operational Problems and Proposed Solutions}

Filter flies and predators are a nuisance in the operation of a TF system. They pose a serious problem to the plant operating staff as well as the neighboring environment and community. It has been reported that species such as Parischnogaster alternata, Pseudocolaspis severini, and Astraeus hygrometricus were abundantly found during TF operation [95]. We also have noticed that ambient air temperature was a major factor influencing the growth of these species [95]. Coombs et al. [96] conducted a study to control the formation of filter flies by using a microbial insecticide such as bacillus thuringiensis var. israelensis (Bti) at Rossendale Sewage Works, Lancashire. The results indicated that the technique was very effective in controlling the filter fly sylvicola fenestralis without changing system performance. Currently, chemical and biological agents are being used to control filter flies and can be removed rapidly from the filter media [95]. Periodic flooding may eliminate filter flies [96]. Another common problem in TF operation is the development of snail populations, which may scuff the slime layer to minimize the nitrifying bacteria population and system performance. The increase in snail populations can cause problems with plugging of channels and pumps, accumulating in digesters, and causing wear and tear on system equipment. Several techniques have been used to control snails (e.g., periodic flooding of the TF system, lowering the distributor speed to create higher flushing rate, high $\mathrm{pH}$ dosing, chlorination saline water dosing, recycling higher levels of ammonia through the process to kill the snails and prevent their growth, and dosing with copper sulfate at $0.4 \mathrm{~g} / \mathrm{L}$ ). All these solutions have some limitations as well [45]. Tekippe et al. [97] reported an alternative way to remove snail shell from TFs by introducing a baffle system in the aeration basins and the use of grit pumps and classifier systems, which were low-cost compared to the previous manual labor method (Table 4).

The operation of TFs is an aerobic process, thus foul odors indicate that anaerobic environments are becoming predominant due to the presence of odor-producing substances such as methyl mercaptan, toluene, alphapinene, hexane, etc. [98-99]. There are several other reasons for foul odors in TFs, such as sloughing off biomass accumulation in the filter media, low oxygen transfer rate (OTR), and uneven moisture content. Loading concentration and oxygen utilization are the main parameters in odor control. It was reported previously that OTR may become inadequate when ultimate BOD value increased from 500 to $600 \mathrm{mg} / \mathrm{L}$, and the chance of odor 
Table 4. Trickling filter system problems, causes, and proposed solutions.

\begin{tabular}{|c|c|c|c|}
\hline Problem(s) & Cause & Solution & Reference \\
\hline \multicolumn{4}{|c|}{ Operational } \\
\hline $\begin{array}{l}\text { Filter flies and } \\
\text { predator }\end{array}$ & $\begin{array}{l}\text { Variation in ambient air } \\
\text { temperature } \\
\text { Long rest period } \\
\text { Uneven running of the system } \\
\text { Uneven distribution of the } \\
\text { influent from nozzle }\end{array}$ & $\begin{array}{c}\text { Apply microbial insecticide for, e.g., Bacillus thuringiensis var } \\
\text { israelensis (Bti) for the control of nuisance fly } \\
\text { Periodically flood the TF System } \\
\text { Lower the distributor arm speed to create a higher flushing rate } \\
\text { High posing } \\
\text { Chlorination with saline water dosing } \\
\text { Recycling higher levels of ammonia through the process to kill } \\
\text { the snails and prevent their growth } \\
\text { Dosing with copper sulfate at } 0.4 \mathrm{~g} / \mathrm{L} \text { for snail removal } \\
\text { Introducing a baffle system to the aeration basins and the use of } \\
\text { grit pumps and classifier systems for snail shell removal } \\
\text { Install birdhouses as a natural technique }\end{array}$ & {$[45,95-97]$} \\
\hline Odors & $\begin{array}{l}\text { Predominant anaerobic } \\
\text { conditions in the system } \\
\text { Excessive biomass accumulation } \\
\text { in the media surface } \\
\text { Improper oxygen transfer rate in } \\
\text { the filter }\end{array}$ & $\begin{array}{c}\text { Pre-aerating and pre-chlorinating the TF influent } \\
\text { Increasing recirculation rate to provide more oxygen to the filter } \\
\text { bed and increase sloughing } \\
\text { Clean the nozzles on a weekly basis for proper influent } \\
\text { distribution } \\
\text { Use chemical scrubbers and sodium hypochlorite doses } \\
\text { Minimize the incoming organic loading by reducing BOD } \\
\text { concentration } \\
\text { Remove slough off biomass by increasing hydraulic loading }\end{array}$ & [98-103] \\
\hline $\begin{array}{l}\text { Nutrient } \\
\text { imbalance }\end{array}$ & $\begin{array}{l}\text { Improper media selection } \\
\text { Uneven hydraulic surface } \\
\text { loading } \\
\text { Uneven development of biofilm }\end{array}$ & $\begin{array}{l}\text { Apply measured nutrient loading to achieve better performance } \\
\text { Keep the TF influent flow warm by minimizing the recirculation } \\
\text { rate }\end{array}$ & $\begin{array}{l}{[13,91} \\
104]\end{array}$ \\
\hline $\begin{array}{l}\text { Weather } \\
\text { concerns }\end{array}$ & $\begin{array}{l}\text { Decrease the biological reaction } \\
\text { rates of the treatment process } \\
\text { Low quality/uneven biofilm } \\
\text { development } \\
\text { Ice clogging the filter, which } \\
\text { causes ponding and structural } \\
\text { damage to the media }\end{array}$ & $\begin{array}{l}\text { Use microwave radiation to maintain required temperature } \\
\text { Periodically flood the TF system to break up the solid }\end{array}$ & {$[13,78-79]$} \\
\hline $\begin{array}{l}\text { Filter } \\
\text { clogging and } \\
\text { ponding }\end{array}$ & $\begin{array}{l}\text { Improper media selection during } \\
\text { targeted pollutant removal } \\
\text { Slough off biomass accumulation } \\
\text { into the void pores } \\
\text { Loss of open area in the filter } \\
\text { Excessive organic loading } \\
\text { Lack of good primary } \\
\text { clarification } \\
\text { Excessive growth of insect larvae } \\
\text { or snails } \\
\text { Shock load and lower transport } \\
\text { of air }\end{array}$ & $\begin{array}{l}\text { Use proper flashing with low doses of chlorine to remove } \\
\text { deposited solids and kill excess biomass } \\
\text { Enhance the recirculation rate } \\
\text { Optimize organic loading and apply low organic loading by } \\
\text { enhancing the performance of a primary settling tank } \\
\text { Replace the TF media if needed }\end{array}$ & {$[13,105]$} \\
\hline $\begin{array}{l}\text { Bio-film } \\
\text { slough off }\end{array}$ & $\begin{array}{l}\text { Clogging the filter media } \\
\text { Changes in waste load } \\
\text { Insufficient nutrients } \\
\text { Uneven distribution of influent } \\
\text { Low moisture content and High } \\
\text { hydraulic loading rate }\end{array}$ & $\begin{array}{l}\text { Optimize organic and hydraulic loading or use a parallel or series } \\
\text { TF system to handle shock variations }\end{array}$ & $\begin{array}{c}{[13,106-} \\
109]\end{array}$ \\
\hline Shock loads & $\begin{array}{l}\text { Strom events will increase the } \\
\text { hydraulic loading, which slough } \\
\text { off the biofilm } \\
\text { Industrial effluents upset the } \\
\text { biological processes and increase } \\
\text { the organic loading or toxic } \\
\text { loading }\end{array}$ & $\begin{array}{l}\text { Neutralized the toxic shock load by using a TF system in series; } \\
\text { this technique will save the biofilm growth } \\
\text { Dilute the toxic shock load by increasing the recirculation rate }\end{array}$ & $\begin{array}{l}{[13,110-} \\
111]\end{array}$ \\
\hline
\end{tabular}


Table 4. Continued.

\begin{tabular}{|c|c|c|c|}
\hline $\begin{array}{l}\text { Distributor } \\
\quad \text { arm }\end{array}$ & $\begin{array}{l}\text { Uneven oxygen utilization } \\
\text { Uneven growth of slime layer } \\
\text { Low BOD and COD removal }\end{array}$ & $\begin{array}{l}\text { Increase the oxygen transfer rate by adjusting the speed of the } \\
\text { distribution arms } \\
\text { Adjust the proper hydraulic flow rate according to system design } \\
\text { Use innovative nozzles in distributor arms to increase system } \\
\text { efficiency }\end{array}$ & $\begin{array}{l}{[13,43,} \\
121-123]\end{array}$ \\
\hline Filter media & $\begin{array}{l}\text { Clogging } \\
\text { Uneven growth of biofilm } \\
\text { Decrease efficiency in terms of } \\
\text { BOD \& COD removal }\end{array}$ & $\begin{array}{l}\text { Use proper media that support the growth of biofilm } \\
\text { Uniform the media by passing through a sieve before installation } \\
\text { Increase the filter media installation width and decrease the depth } \\
\text { Apply active aeration to increase operational efficiency }\end{array}$ & $\begin{array}{c}\text { Table } 1 \\
\& 2\end{array}$ \\
\hline \multicolumn{4}{|c|}{ Performance } \\
\hline $\begin{array}{l}\text { High total } \\
\text { suspended } \\
\text { solids }\end{array}$ & Excessive biomass sloughing & $\begin{array}{l}\text { Optimize the hydraulic loading rate (HRT) } \\
\text { Use proper flushing if slough-off of biomass is excessive }\end{array}$ & $\begin{array}{l}{[13,95,99,} \\
117]\end{array}$ \\
\hline $\begin{array}{l}\text { High } \\
\text { biochemical } \\
\text { oxygen } \\
\text { demand }\end{array}$ & $\begin{array}{l}\text { Increase in organic loading rate } \\
\text { Anaerobic conditions in the } \\
\text { system } \\
\text { Low oxygen transfer rate } \\
\text { Improper slime layer growth in } \\
\text { the media surface }\end{array}$ & $\begin{array}{c}\text { Optimize the loading and remove the clogging and slough-off } \\
\text { biomass by proper flushing } \\
\text { Optimize weather conditions by artificial means for keeping } \\
\text { optimum oxygen transfer rate (OTR) }\end{array}$ & {$[13,101]$} \\
\hline $\begin{array}{l}\text { High } \\
\text { settleable } \\
\text { solids }\end{array}$ & Uneven sloughing of slime layer & $\begin{array}{l}\text { Minimize the shock loads and optimize the loading rate or use a } \\
\text { TF system in series to handle shock loads }\end{array}$ & {$[13,99]$} \\
\hline $\begin{array}{l}\text { Low } \\
\text { dissolved } \\
\text { oxygen }\end{array}$ & $\begin{array}{l}\text { Mixing of industrial waste due } \\
\text { to odor }\end{array}$ & $\begin{array}{l}\text { Optimize the loading and oxygen transfer rate (OTR) } \\
\text { Increase recirculation rate }\end{array}$ & {$[13]$} \\
\hline $\begin{array}{l}\text { High chlorine } \\
\text { demand }\end{array}$ & $\begin{array}{l}\text { Filter clogging and poor oxygen } \\
\text { transfer } \\
\text { Improper distribution of influent }\end{array}$ & $\begin{array}{l}\text { Control the industrial effluents or shock loads and enhance } \\
\text { primary settling tank efficiency for removing solids from TF } \\
\text { influents }\end{array}$ & {$[13,120]$} \\
\hline $\begin{array}{l}\text { Low or high } \\
\quad \mathrm{pH}\end{array}$ & $\begin{array}{l}\text { Mixing of industrial wastewater } \\
\text { in influent during VOC } \\
\text { degradation } \\
\text { Anaerobic conditions in the } \\
\text { system }\end{array}$ & $\begin{array}{l}\text { Try to neutralized the TF influents by using buffer materials for, } \\
\text { e.g., calcium carbonate and dolomite } \\
\text { Use nutrient solution, for example } \mathrm{Ca}(\mathrm{OH})_{2}, \mathrm{NaOH}, \mathrm{NaHCO}_{3} \text {, and } \\
\text { urea }\end{array}$ & $\begin{array}{l}{[13,126,} \\
129]\end{array}$ \\
\hline $\begin{array}{l}\text { Biofilm/Slime } \\
\text { layer }\end{array}$ & $\begin{array}{c}\text { Improper media selection } \\
\text { Uneven nutrients supply } \\
\text { Uneven aeration } \\
\text { High organic and hydraulic } \\
\text { loading rates } \\
\text { Uneven sloughing } \\
\text { Weather Conditions }\end{array}$ & $\begin{array}{c}\text { Control the slime layer thickness by sloughing process } \\
\text { Create aerobic conditions by maintaining optimum oxygen } \\
\text { transfer rate } \\
\text { Use good filter media that support microbial growth } \\
\text { Use a chemical addition like ferric chloride and polymers to } \\
\text { enhanced the growth of the slime layer and also trickling filter } \\
\text { efficiency } \\
\text { Use optimum oxygen levels for proper growth of bio-film } \\
\text { Optimum amounts of nutrient solutions can be applied for } \\
\text { microbial growth } \\
\text { Increase the DO level of influent by recirculating the effluent } \\
\text { Optimize the organic loading rate to maintain bio-film structure }\end{array}$ & $\begin{array}{l}{[13,23,80,} \\
136-143]\end{array}$ \\
\hline
\end{tabular}

production will also increase [100]. The moisture content of the media bed is a key element for maintaining TF performance because of a bacterium's required optimal moisture to perform their metabolic activity [101]. The imbalance level of moisture content leads to drying of the filter bed and may cause channeling and short-circuiting [102]. Moreover, the rate of biodegradation will also lower [103]. Chemical scrubbers and sodium hypochlorite dosage can be used for controlling odor, as illustrated in detail in Table 4.

The optimum level of $\mathrm{C}: \mathrm{N}: \mathrm{P}$ (redfield ratio) are the key nutrients for growing and reproducing biofilm in TF operation [91]. Although municipal wastewater normally contains a suitable quantity of nutrients, its concentration varies in the case of industrial effluents [104]. It was reported previously that the shape and type of filter media may also influence nitrification performance and biofilm development due to nutrient imbalance [105-106] (Table 4). The environmental conditions such as air and influent temperatures have an effect on TF operation that eventually influences TF performance [104]. Cold weather can lower the degradation rate of pollutants and reduce the growth of slime layer in the TF systems. While under very low temperatures, ice clogging causes the bonding 
effect in TF systems. It was also observed that biofilm thickness also fluctuates seasonally and the thickness was increased in winter and decreased in summer [13, 79]. Natural ventilation has historically been the primary means of providing airflow, but it is not always adequate and forced ventilation using low-pressure fans to provide more reliable and controlled airflow [78]. Naz et al. [79] conducted a study and reported that most of the microorganisms flourish well in the temperature range $25-40^{\circ} \mathrm{C}$. However, greater detail regarding the effect of weather on TF performance is discussed in Table 4.

Ponding is another problem regarding the collection of wastewater on the surface and results in complete choking of the TFs. Major causes of ponding include excessive organic loading, insufficient recirculation, improper or no primary clarification, small-sized media or non-uniform media, accumulation of fibers or trash in the interstices, excessive slough-off, and excessive growth of insect larvae, snails or, other insects [13, 105]. Further details of the various causes and suggestions to solutions for ponding are discussed in Table 4. Moreover, uncontrolled sloughing from the filter media is one of the most common problems in TF operations [13]. It may occur due to uneven hydraulic loading rates (HLR) or sheering force of the influents [106]. Wik [107] reported that low organic loading may not clog the TF system. Moreover, periodic recirculation of the TF system with water/wastewater may control the biofilm slough off problem [108-109]. Details about different issues of sloughing and its solution approaches are given in detail in Table 4.

Storm events and industrial discharge also are identified as two main factors of shock loads in TF operations as inflow increases the HLR to the plant [110]. The high loading rate consequently forces the slime layer to slough off the filter media. The oil factory organics or other toxic chemicals are allowed to enter the treatment plant without specialized treatment provisions, and the biological process is hindered and disturbed. The organisms might become inactivated or completely die. Industrial discharges can either increase the organic loading rate or the toxic shock loading, or both. Increased organic loading rate depletes the oxygen and microorganisms die off. Biological growth sloughs off clogging the filter and ultimately resulting in ponding. Increased toxic loads disturb the microbial populations [111] (Table 4).

The distributor arm is the main parameter in design of TF systems because it helps in uniform distribution of wastewater into filter media and maintains a proper wetting for slime layer growth [13, 112-114]. Maulik [43] conducted a study to apply special nozzles with a flat spray pattern for constant distribution of influents and reported that such nozzles can enhance the influent distribution pattern over the filter media, but could not improve OTR (detailed discussion about different designs of the distribution arms is available in Table 4). Moreover, filter media in TFs support slime layer growth, and selection of the suitable support media is very important for TF operation and performance. The filter media play a vital role in development of the microbial community/ biofilm. The performance of TFs varies with media to media due to its surface, depth, and size. Scientists have used several packing media to enhance TF performance, e.g., rocks, plastic [13], nylon pot scrubber [77], groups of commercial rings (such as crushed leca, kaldnes, and Norton), calcitic gravel [115-116], geotextile [117], pall rings [118], polyurethane foam pores [119], coal cinder [42], tire-derived rubber [45], oyster shell [120], corrugated plastic sheet [41], stone [70], gravel and zeolite [118] sponge [38], zeolite and ceramsite [40], polypropylene plastic [39], biochar chips [44], ceramic particles [121], etc. (Brief summaries of the different filter media used in TFs with their targeted pollutants removed are given in Tables 2 and 3). It was also reported that TF performance can be enhanced by maintaining media surface wetting and maintaining the aerobic environment during operation [122]. Wang et al. [119] reported the performance of hybrid biological rectors using polyurethane foam pores as filter media and observed that the total biomass concentration in hybrid reactors increased to $4.30-5.75 \mathrm{~g} / 1$ when the volumetric portion of the carrier was $15-30 \%$. Kumar et al. [123] reported the performance comparison of two different biogenic filter materials (such as corn cobs and wood chips) inoculated with a defined microbial community. Corn cobs of specified dimensions were found to be more suitable than wood chips. Corn cobs with hollow surface produced remarkable results. The time duration was also less for initiation of purification activity. Yao et al. [124] reported the removal efficiency by comparing the oyster shell and plastic ball used as filter medium for the treatment of municipal wastewater in two lab-scale upflow biological aerated filters (BAFs) under different HRTs of 2, 4, 8, and $12 \mathrm{~h}$. Further detail is discussed in Table 4.

\section{Trickling Filter Performance Issues and Solution Approaches}

The higher concentration of the total suspended solids (TSS) in the TF effluents may be caused due to uncontrolled biomass slough-off. High HLR displace the solids from the primary clarifier to the TFs and also cause the biofilm to strip off [99]. On the other hand, less than optimum HLR to the system makes the biofilm slough off [95]. Clogging occurs due to the presence of high solids or sloughed-off biological growth and creates an anaerobic environment that destabilizes the process $[13,125]$. It might occur due to inadequate ventilation in the filter media $[13,99]$. If the industrial effluents are allowed to enter the influent stream of the wastewater treatment plant, it may cause high chlorine demand [96]. If excessive slough off is there, TSS will be high in the effluent and will exert a high chlorine demand. This may cause failure to gain downstream disinfection [95, 98-99]. While $\mathrm{pH}$ can be considered as the main checking parameter of TF performance, septic conditions typically are caused in wastewater due to increases in $\mathrm{pH}[78,126]$. $\mathrm{pH}$ can vary due to industrial effluent discharges, depending on the type of industry. 
Microbial activity is influenced due to variation in influent $\mathrm{pH}$ [127]. Lu et al. [128] reported maximum degradation of Benzene, Toluene, Ethylbenzene, and Xylenes (BTEX) between $\mathrm{pH}$ values of 7.5 and 8.0. Lu et al. [128] also reported a $\mathrm{pH}$ of 7.0 to be optimal for BTEX degradation. Arnold et al. [129] reported styrene eliminations were enhanced in a neutral medium. To keep the $\mathrm{pH}$ (at 7) some scientists have reported supplementing buffer solutions in the media beds for, e.g., calcium carbonate [130-131] and dolomite [132]. The $\mathrm{pH}$ can also be controlled by bed irrigation of nutrient solutions that contain $\mathrm{pH}$ buffers, for example $\mathrm{Ca}(\mathrm{OH})_{2}, \mathrm{NaOH}$ [133], $\mathrm{NaHCO}_{3}$ [134], and urea [135] (Table 4).

Biofilm is the community of organisms; a key element of TFs developing on the surface of the support media is carrying out catabolic activity and transforming the pollutants into harmless products [136]. The thickness and shape of the biofilm is influenced by several environmental factors such as the type of pollutant, packing material used, ambient air and wastewater temperature, humidity, moisture content, system design, and configuration of the treatment system [13, 23, 137]. Wijeyekoon et al. [112] reported that organic loading influenced biofilm internal microstructure as with the increased organic load that produced a compact biofilm layer with lower porosity. It was reported that TF filter media should possess high specific surface area, high porosity, good water retention capacity, availability of intrinsic nutrients, and the presence of a dense and diverse indigenous microflora [138]. Further, various approaches for the development of metabolically competent biofilm on the filter media of the TFs are discussed in Table 4.

\section{Conclusions}

Given the deplorable situation of wastewater treatment in developing countries, it is imperative to explore costeffective, technically less complicated, and less energyconsuming treatment options. Conventional systems like activated sludge do not fit in this criterion and either new treatment systems have to be developed indigenously or the available technologies must be appropriately modified before implementation to make them appropriate for local conditions. The trickling filter in this regard is potentially a viable option, as it is a simple and reliable biological treatment process and an appropriate option for smallto medium-sized communities, and requires less space and time for removal of $\mathrm{BOD}_{5}$. It has durable process elements, low power requirements, a moderate level of technical training requirement for the staff, and resilience against power failures and shock loads. However, TFs have their own limitations, performance issues/operational troubles identified in the present review paper, and the corresponding solutions/approaches are also suggested for smooth and satisfactory operation.

Wastewater management and treatment is indeed an alarming appeal for developing countries because wastewater contains biodegradable and non-degradable organic and inorganic matter, toxic chemicals, and disease-causing organisms that can destroy public health. The mixing of untreated wastewater into natural receiving water is polluting drinking water sources - both surface and ground. While the parameters set by WHO and Pak EPA related to wastewater disposal and drinking water are frequently violated, the situation of wastewater management and treatment is not acceptable because only about $6 \%$ of wastewater is receiving treatment before disposal. Therefore, this review paper was designed to propose a suitable and affordable wastewater treatment system for developing countries like Pakistan, India, Bangladesh, and African regions, etc. Keeping in mind the past experiences and problems, the trickling filter is a suitable and viable option for developing countries. Although past practice was not good, this was only due to lack of technical knowledge and trained human resources. This review paper is an effort to present the importance of the trickling filter system with special emphasis on identifying the operational and performance issues that mainly hindered its operation. Furthermore, corresponding solutions are also suggested against each problem for its smooth running.

\section{Acknowledgements}

This work was supported by the State Key Laboratory of Environmental Criteria and Risk Assessment (No. SKLECRA 2013FP12) and the Shandong Province Key Research and Development Program (2016GSF115040). The first author would also like to thank the Chinese Scholarship Council, China for its financial support (CSC No: 2016GXYO20).

\section{References}

1. HAIDER R., YASAR A., TABINDA A.B. Urban Emission Patterns at a Semi-Arid Site in Lahore, Pakistan. Pol. J. Environ. Stud. 26 (1), 5, 2017.

2. QURESHI M.A., MASTOI G.M. The physiochemistry of sugar mill effluent pollution of coastlines in Pakistan. Ecol. Eng. 75, 137, 2011.

3. SHAH M., HASHMI H.N. Macrophyte waste stabilization ponds: An option for municipal wastewater treatment. Int. J. Phys. Sci. 7 (30), 5162, 2012.

4. GU W., CHENG B., LI Y. Interference Adsorption of Cadmium with a Variety of Pollutants in Sediments Based on Fractional Factorial Design (Resolution V). Pol. J. Environ. Stud. 26 (1), 47, 2017.

5. ALI N., EQANI S., MALIK R.N., NEELS H., COVACI, A. Organohalogenated contaminants (OHCs) in human serum of mothers and children from Pakistan with urban and rural residential settings. Sci. Total. Environ. 461, 655, 2013.

6. PUNRATTANASIN P., SARIEM P. Adsorption of copper, zinc, and nickel using loess as adsorbents. Pol. J. Environ. Stud. 24, 1259, 2015.

7. MURTAZA G., GHAFOOR A., QADIR M., OWENS G., AZIZ M.A., ZIA M.H. Disposal and Use of Sewage on Agricultural Lands in Pakistan: A Review. Pedosphere. 20 (1), 23, 2010. 
8. SYED J.H., MALIK R.N., LI J., CHAEMFA C., ZHANG, G., JONES K.C. Status, distribution and ecological risk of organochlorines (OCs) in the surface sediments from the Ravi River, Pakistan. Sci. Total Environ. 472, 204, 2014.

9. QADIR M., WICHELNSC D., RASCHID-SALLY L., MCCORNICK P.G., DRECHSEL P., BAHRI A. MINHAS P.S. The challenges of wastewater irrigation in developing countries. Agr. Water Manage. 97 (4), 561, 2014.

10. HASHMI M.Z., MALIK R.N., SHAHBAZ M. Heavy metals in eggshells of cattle egret (Bubulcus ibis) and little egret (Egretta garzetta) from the Punjab province, Pakistan. Ecotoxicol. Environ. Saf. 89, 158, 2013.

11. PUNRATTANASIN P., SARIEM P. Adsorption of copper, zinc, and nickel using loess as adsorbents. Pol. J. Environ. Stud. 24, 1259, 2015.

12. SUROVKA D., PERTILE E. Sorption of Iron, Manganese, and Copper from Aqueous Solution Using Orange Peel: Optimization, Isothermic, Kinetic, and Thermodynamic Studies. Pol. J. Environ. Stud. 26 (2), 795, 2017.

13. METCALF E., EDDY H.P. Wastewater Engineering: Treatment, Disposal, and Reuse. Chapter 9, $4^{\text {th }}$ ed, The McGraw-Hill Companies, New York. 1456, 2003.

14. HAMZA R.A., OLIVER T.I., JOO H.T. Advances in biological systems for the treatment of high-strength wastewater. J. Water Process Eng. 10, 128, 2016.

15. BOUABID A., LOUIS G.E. Capacity factor analysis for evaluating water and sanitation infrastructure choices for developing communities. J. Environ. Manage. 161, 335, 2015.

16. TĂNASE A.M., CHICIUDEAN I., MEREUȚĂ I., IONESCU R., CORNEA C.P., VASSU T., STOICA I. Microbial Community Dynamics in Field-Scale Biopile Bioremediation. Pol. J. Environ. Stud. 26 (1), 331, 2017.

17. PALIULIS D. Removal of formaldehyde from synthetic wastewater using natural and modified zeolites. Pol. J. Environ. Stud. 25 (1), 251, 2017.

18. IRSHAD M., AHMAD S., PERVEZ A., INOUE M. Phytoaccumulation of heavy metals in natural plants thriving on wastewater effluent at hattar industrial estate, Pakistan. Int. J. Phytoremediat. 17 (2), 154, 2015.

19. IJAZ A., SHABIR G., KHAN Q.M., AFZAL M. Enhanced remediation of sewage effluent by endophyte-assisted floating treatment wetlands. Ecol. Eng. 84, 58, 2015.

20. AFTAB B., KHAN S.J., MAQBOOL T., HANKINS N.P. High strength domestic wastewater treatment with submerged forward osmosis membrane bioreactor. 72 (1), $141,2015$.

21. SHAH M., HASHMI H.N., ALI A., GHUMMAN A.R. Performance assessment of aquatic macrophytes for treatment of municipal wastewater. J. Environ. Health Sci. Eng. 12, 1, 2014.

22. SEHAR S., NAEEM S., PERVEEN I., ALI N., AHMED S. A comparative study of macrophytes influence on wastewater treatment through subsurface flow hybrid constructed wetland. Ecol. Eng. 81, 62, 2015.

23. NAZ I., SAROJ D.P., MUMTAZ S., ALI N., AHMED S. Assessment of biological trickling filter systems with various packing materials for improved wastewater treatment. Environ. Technol. 36 (4), 424, 2015a.

24. HINA K., HEDLEY M., CAMPS-ARBESTAIN M., HANLY J. Comparison of Pine Bark, Biochar and Zeolite as Sorbents for NH4+N Removal from Water. Clean-Soil, Air, Water. 43, 86, 2015.

25. HAYAT H., MAHMOOD Q., PERVEZ A., BHATTI Z.A., BAIG S.A. Comparative decolorization of dyes in textile wastewater using biological and chemical treatment. Sep. Purif. Technol. 154, 149, 2015.

26. FAZAL S., ZHANG B., MEHMOOD Q. Biological treatment of combined industrial wastewater. Ecol. Eng. 84, $551,2015$.

27. BHATTI H., SADAF S., ALEEM A. Treatment of Textile Effluents by Low Cost Agricultural Wastes: Batch Biosorption Study JAPS. J. Anim. Plant Sci. 25, 284, 2015.

28. BILAL M., ASGHER M. Sandal reactive dyes decolorization and cytotoxicity reduction using manganese peroxidase immobilized onto polyvinyl alcohol-alginate beads. Chem. Cent. J. 9, 1, 2015.

29. BHATTI Z.A., MAQBOOL F., MALIK A.H., PERVEZ A., MAHMOOD Q. Municipal wastewater minimization through waste $\mathrm{H}_{2} \mathrm{O}_{2}$ from food industry. Desalin. Water Treat. 4, 1, 2014.

30. KHAN Z.U., NAZ I., REHMAN A., RAFIQ M., ALI N. AHMED S. Performance efficiency of an integrated stone media fixed biofilm reactor and sand filter for sewage treatment. Desalin. Water Treat. 54, 2638, 2014.

31. MAQBOOL T., KHAN S.J., LEE C.H. Effects of filtration modes on membrane fouling behavior and treatment in submerged membrane bioreactor. Bioresour. Tech. 172, 391, 2014.

32. SEHAR S., AAMIR R., NAZ I., ALI N., AHMED S. Reduction of contaminants (physical, chemical, and microbial) in domestic wastewater through hybrid constructed wetland. ISRN Microbiol. 2013.

33. NAZ I., KHATOON N., ALI M.I., SAROJ D.P., BATOOL S.A.U., ALI N. AHMED S. Appraisal of the tire derived rubber (TDR) medium for wastewater treatment under aerobic and anaerobic conditions. J. Chem. Technol. Biotechnol. 89 (4), 587, 2014.

34. BHATTI Z.A., MAHMOOD Q., RAJA I.A., MALIK A.H., KHAN M.S., WU D. Chemical oxidation of carwash industry wastewater as an effort to decrease water pollution. Phys. Chem. Earth, Parts A/B/C. 36, 465, 2011.

35. KHAN S., AHMAD I., SHAH M.T., REHMAN, S., KHALIQ A. Use of constructed wetland for the removal of heavy metals from industrial wastewater. J. Environ. Manag. 90, 3451, 2009.

36. ASLAM M.M., MALIK M., BAIG M., QAZI I.A., IQBAL J. Treatment performances of compost-based and gravelbased vertical flow wetlands operated identically for refinery wastewater treatment in Pakistan. Ecol. Eng. 30, 34, 2007.

37. KHAN M.A., KHAN M.A. The potential of waste stabilization ponds effluent as a liquid fertilizer. Pak. J. Bot. 39, 817, 2007.

38. WANG H., JI G., BAI X., HE C. Assessing nitrogen transformation processes in a trickling filter under hydraulic loading rate constraints using nitrogen functional gene abundances. Bioresour. Technol. 177, 17, 2015.

39. LEI M., VAN DEN AKKER B., DU J., KOOKANA R.S., FALLOWFIELD H. Impact of exogenous organic carbon on the removal of chemicals of concern in the high rate nitrifying trickling filters. J. Enviro. Manag. 174, 7, 2016.

40. ZHANG X., LI J., YU Y., XU R., WU Z. Biofilm characteristics in natural ventilation trickling filters (NVTFs) for municipal wastewater treatment: Comparison of three kinds of biofilm carriers. Biochem. Eng. J. 106, 87, 2016.

41. KIM B., GAUTIER M., PROST-BOUCLE S., MOLLE P., MICHEL P., GOURDON, R. Performance evaluation of partially saturated vertical-flow constructed wetland with trickling filter and chemical precipitation for domestic and winery wastewaters treatment. Ecol. Eng. 71, 41, 2014. 
42. QINGLIANG Z., HUIYUAN Z., KUN W. Removal and transformation of organic matters in domestic wastewater during lab-scale chemically enhanced primary treatment and a trickling filter treatment. J. Environ. Sci. 25 (1), 59, 2013.

43. MAULIK M.N. Wastewater treatment and sewage disposal. $1^{\text {st }}$ ed, Rajinder Kumar Jain. 1997; PP 178-198.

44. LI W., LOYOLA-LICEA C., CROWLEY D.E., AHMAD Z. Performance of a two-phase biotrickling filter packed with biochar chips for treatment of wastewater containing high nitrogen and phosphorus concentrations. Process Saf. Environ. Prot. 102, 150, 2016.

45. WEF. Aerobic Fixed Growth Reactors, Water Environment Federation, Alexandeia, VA. 345, 2000.

46. VAYENAS D.V., LYBERATOS G. On The Design of Nitrifying Trickling Filters for Potable Water Treatment. Water Res. 29 (4), 1079, 1995.

47. MICHALAKOS G.D., NIEVA J.M., VAYENAS D.V., LYBERATOS G. Removal of iron from potable water using a trickling filter. Water Res. 31 (5), 991, 1997.

48. GOUZINIS A., KOSMIDIS N., VAYENAS D.V., LYBERATOS G. Removal of Mn and simultaneous removal of $\mathrm{NH}_{3}, \mathrm{Fe}$ and $\mathrm{Mn}$ from potable water using a trickling filter. Water Res. 32 (8), 2442, 1998.

49. DERMOU E., VELISSARIOU A., XENOS D., VAYENAS D.V. Biological chromium (VI) reduction using a trickling filter. J. Hazard. Mater. 126 (1), 78, 2005.

50. TEKERLEKOPOULOU A.G., VASILIADOU I.A., VAYENAS D.V. Physico-chemical and biological iron removal from potable water. Biochem. Eng. J. 31 (1), 74, 2006.

51. DERMOU E., VELISSARIOU A., XENOS D., VAYENAS D.V. Biological removal of hexavalent chromium in trickling filters operating with different filter media types. Desalination. 211 (1), 156, 2007.

52. TEKERLEKOPOULOU A.G., VASILIADOU I.A., VAYENAS D.V. Biological manganese removal from potable water using trickling filters. Biochem. Eng. J. 38 (3), $292,2008$.

53. VAN DEN AKKER B., HOLMES M., CROMAR N., FALLOWFIELD $\mathrm{H}$. Application of high rate nitrifying trickling filters for potable water treatment. Water Res. 42 (17), 4514, 2008.

54. VASILIADOU I.A., KARANASIOS K.A., PAVLOU S., VAYENAS D.V. Hydrogenotrophic denitrification of drinking water using packed-bed reactors. Desalination. 248 (1), 859, 2009.

55. VASILIADOU I.A., KARANASIOS K.A., PAVLOU S., VAYENAS D.V. Experimental and modelling study of drinking water hydrogenotrophic denitrification in packedbed reactors. J. Hazard. Mater. 165 (1), 812, 2009.

56. TEKERLEKOPOULOU A.G., VAYENAS D.V. Ammonia, iron and manganese removal from potable water using trickling filters. Desalination. 210 (1), 225, 2007.

57. GRAY N.F., LEARNER M.A. Comparative pilot-scale investigation into uprating the performance of percolating filters by partial medium replacement. Water Res. 18 (4), 409, 1984.

58. HUA J., AN P., WINTER J. GALLERT C. Elimination of COD, microorganisms and pharmaceuticals from sewage by trickling through sandy soil below leaking sewers. Water Res. 37 (18), 4395, 2003.

59. KORNAROS M., LYBERATOS G. Biological treatment of wastewaters from a dye manufacturing company using a trickling filter. J. Hazard. Mater. 136 (1), 95, 2006.

60. ZIOLKO D., HALA D., LESTER J.N., SCRIMSHAW M.D. The effectiveness of conventional trickling filter treatment plants at reducing concentrations of copper in wastewaters. Sci. Total Environ. 407 (24), 6235, 2009.

61. NOVOTNÝ Č., SVOBODOVÁ K., BENADA O., KOFROŇOVÁ O., HEISSENBERGER A., FUCHS W. Potential of combined fungal and bacterial treatment for color removal in textile wastewater. Bioresour. Technol. 102 (2), 879, 2011.

62. ZHAO Q., ZHONG H., WANG K., WEI L., LIU, J., LIU Y. Removal and transformation of organic matters in domestic wastewater during lab-scale chemically enhanced primary treatment and a trickling filter treatment. J. Environ. Sci. 25 (1), 59, 2013.

63. JIANLONG W., HANCHANG S., YI Q. Wastewater treatment in a hybrid biological reactor (HBR): effect of organic loading rates. Proc. Biochem. 36 (4), 297, 2000.

64. JARVIS A.P., YOUNGER P.L. Passive treatment of ferruginous mine waters using high surface area media. Water Res. 35 (15), 3643, 2001.

65. TZIOTZIOS G., LYBERATOS G., PAVLOU S., VAYENAS D.V. Modelling of biological phenol removal in draw-fill reactors using suspended and attached growth olive pulp bacteria. Internat. Biodeterior. Biodegra. 61 (2), 142, 2008.

66. TZIOTZIOS G., TELIOU M., KALTSOUNI V., LYBERATOS G., VAYENAS D.V. Biological phenol removal using suspended growth and packed bed reactor. Biochem. Eng. J. 26 (1), 65, 2009.

67. VAYENAS D.V., MICHALOPOULOU E., CONSTANTINIDES G.N., PAVLOU S., PAYATAKES A.C. Visualization experiments of biodegradation in porous media and calculation of the biodegradation rate. Adv. Water Resour. 25 (2), 203, 2002.

68. SIMSEK H., KASI M., OHM J.B., BLONIGEN M., KHAN, E. Bioavailable and biodegradable dissolved organic nitrogen in activated sludge and trickling filter wastewater treatment plants. Water Res. 47 (9), 3201, 2013.

69. DERMOU E., VAYENAS D.V. Biological Cr (VI) reduction in a trickling filter under continuous operation with recirculation. J. Chem. Technol. Biotechnol. 83, 871, 2008.

70. KHAN Z.U., NAZ I., REHMAN A., et al. Performance efficiency of an integrated stone media fixed biofilm reactor and sand filter for sewage treatment, Desalin. Water Treat. 54 (10), 2638, 2015.

71. LEKANG O.I., KLEPPE H. Efficiency of nitrification in trickling filters using different filter media. Aquacult. Eng. 21 (3), 181, 2000

72. MORTON A., AUVERMANN B. Comparison of plastic trickling filter media for the treatment of swine lagoon effluent. In 2001 ASAE Annual Meeting. A.S.A.B.E. 1998; PP. 1.

73. LIU Y.X., YANG T.O., YUAN D.X., WU X.Y. Study of municipal wastewater treatment with oyster shell as biological aerated filter medium. Desalination. 254 (1), 149, 2010.

74. LUO H., HUANG G., FU X., LIU X., ZHENG D., PENG J., ZHANG K., HUANG B., FAN L., CHEN F., SUN X. Waste oyster shell as a kind of active filler to treat the combined wastewater at an estuary. J. Environ. Sci. 25 (10), 2047, 2010.

75. VIANNA M.R., MELO G.C., NETO M.R. Wastewater Treatment in Trickling Filters using Luffa cyllindrica as Biofilm Supporting Medium, J.U.E.E. 6 (2), 57, 2012.

76. ALIMAHMOODI M., YERUSHALMI L., MULLIGAN C.N. Development of biofilm on geotextile in a new multizone wastewater treatment system for simultaneous removal of COD, nitrogen and phosphoru. Bioresour. Technol. 107, 78, 2012. 
77. SANJIB M., MOHD, MUKHERJEE C.K. Evaluation of nitrification performance of a trickling filter with nylon pot scrubber as media. I.J.S.N. 2 (3), 515, 2011.

78. REHMAN A., NAZ I., KHAN Z.U., RAFIQ M., NAEEM A., AHMAD S. Sequential application of plastic mediatrickling filter and sand filter for domestic wastewater treatment at low temperature condition. Brit. Biotechnol. J. 2 (4), 179, 2012.

79. NAZ I., ULLAH W., SEHAR S., REHMAN A., KHAN Z.U., ALI N., AHMED, S. Performance evaluation of stonemedia pro-type pilot-scale trickling biofilter system for municipal wastewater treatment. Desalin. Water Treat. 57 (34), 15792, 2016.

80. WU H., YIN Z., QUAN Y., FANG Y., YIN C. Removal of methyl acrylate by ceramic-packed biotrickling filter and their response to bacterial community. Bioresour. Technol. 209, 237, 2016.

81. OLIVER R., MAY E., WILLIAMS J. The occurrence and removal of phthalates in a trickle filter STW. Water Res. 39 (18), 4436, 2005.

82. AHAMMAD S.Z., ZEALAND A., DOLFING J., MOTA C., ARMSTRONG, D.V., GRAHAM D.W. Low-energy treatment of colourant wastes using sponge biofilters for the personal care product industry. Bioresour. Technol. 129, 634, 2013.

83. ZAPICO R.R., MARÍN P., DÍEZ F.V., ORDÓÑEZ, S. Performance of ceramic foams as gas-liquid contactors for phenol wet oxidation in the trickle regime. Catal. Today. 273, 172, 2016.

84. SKYBOVÁ T., PŘIBYL M., POCEDIČ J., HASAL P. Mathematical modeling of wastewater decolorization in a trickle-bed bioreactor. J. Biotechnol. 157, 512, 2012.

85. WU S., QI Y., YUE Q., GAO B., GAO Y., FAN C., HE S. Preparation of ceramic filler from reusing sewage sludge and application in biological aerated filter for soy protein secondary wastewater treatment. J. Hazard. Mater. 283, 608, 2015.

86. SA C.S.A., BOAVENTURA R.A.R. Biodegradation of phenol by Pseudomonas putida DSM 548 in a trickling bed reactor. Biochem. Eng. J. 9 (3), 211, 2001.

87. EVANGELHO M.R., GONCALVES M.M.M., SANT'ANNA G.L., BOAS R.V. A trickling filter application for the treatment of a gold milling effluent. Int. Miner. Process. 62 (1), 279, 2001.

88. MATTHEWS R., WINSON M., SCULLION J. Treating landfill leachate using passive aeration trickling filters; effects of leachate characteristics and temperature on rates and process dynamics. Sci. Total Environ. 407 (8), 2557, 2009.

89. GUILLEN J.S., JAYAWARDANA L., VAZQUEZ C.L., DE OLIVEIRA CRUZ L.M., BRDJANOVIC D., VAN LIER J.B. Autotrophic nitrogen removal over nitrite in a spongebed trickling filter. Bioresour. Technol. 187, 314, 2015.

90. ZHANG X., LI J., YU Y., XU R., WU, Z. Biofilm characteristics in natural ventilation trickling filters (NVTFs) for municipal wastewater treatment: Comparison of three kinds of biofilm carriers. Biochem. Eng. J. 106, 87, 2016.

91. GUILLÉN J.S., GUARDADO P.C., VAZQUEZ C.L., DE OLIVEIRA CRUZ L.M., BRDJANOVIC D., VAN LIER J.B. Anammox cultivation in a closed sponge-bed trickling filter. Bioresour. Technol. 186, 252, 2015.

92. KIM B., GAUTIER M., MOLLE P., MICHEL P., GOURDON R. Influence of the water saturation level on phosphorus retention and treatment performances of vertical flow constructed wetland combined with trickling filter and $\mathrm{FeCl}_{3}$ injection. Ecol. Eng. 80, 53, 2015.
93. PUHULWELlA R.G., BECKERS L., DELVIGNE F., GRIGORESCU A.S., THONART, P., HILIGSMANN $\mathrm{S}$. Mesophilic biohydrogen production by Clostridium butyricum CWBI1009 in trickling biofilter reactor. Int. J. Hydrogen Energy 39 (30), 16902, 2014.

94. ALI I., KHAN Z.M., SULTAN M., MAHMOOD M.H., FARID H.U., ALI M., NASIR A. Experimental Study on Maize Cob Trickling Filter-Based Wastewater Treatment System: Design, Development, and Performance Evaluation. Pol. J. Environ. Stud. 25 (6), 2265, 2016.

95. LEARNER M.A. Egression of flies from sewage filterbeds. Water Res. 34 (3), 877, 2000.

96. COOMBS R.M., DANCER B.N., DAVIES D.H., HOUSTON J., LEARNER, M.A. The use of Bacillus thuringiensis var. israelensis to control the nuisance fly Sylvicola fenestralis (Anisopodidae) in sewage filter beds. Water Res. 25 (5), 605, 1991.

97. TEKIPPE T.R., HOFFMAN R.J., MATHESON R.J., POMEROY B. A Simple Solution to Big Snail Problems-A Case Study at VSFCD's Ryder Street Wastewater Treatment Plant. Proceedings of the Water Environment Federation. 10, 2547, 2006.

98. RAQUEL L., ELISA R., JOSE M.E., GARCÍA-ENCINA P.A., MUÑOZ R. Odor abatement in biotrickling filters: Effect of the EBRT on methyl mercaptan and hydrophobic VOCs removal. Bioresour. Technol. 109, 38, 2012.

99. HENZE M., HARREMOES P., LA COUR JANSEN J., ARVIN E. Wastewater treatment: biological and chemical processes, Springer Science \& Business Media. 367, 2001.

100. SCHROEDER E.D., TCHOBANGLOUS G. Mass transfer limitations on trickling filter design. J. Water Pollut. Control Fed. 48, 771, 1976.

101. PATRIA L., CATHELAIN M., LAURENS P., BARBERE J.P. Odour removal with a trickling filter at a small WWTP strongly influenced by the tourism season. Water Sci. Technol. 44 (2-3), 243, 2001.

102. SHAREEFDEEN Z., SINGH A. Biotechnology for Odor and Air Pollution Control. Biotech, Springer. 378, 2005.

103. TSANG Y.F., CHUA H., SIN S.N., CHAN S.Y. Treatment of odorous volatile fatty acids using a biotrickling filter. Bioresour. Technol. 99 (3), 589, 2008.

104. ZIELINSKI M., ZIELINSKA M., DĘBOWSKI M. Application of microwave radiation to biofilm heating during wastewater treatment in trickling filters, Bioresour. Technol. 127, 223, 2013.

105. ILIUTA I. Modeling simultaneous biological clogging and physical plugging in trickle-bed bioreactors for wastewater treatment. Chem. Eng. Sci. 60 (5), 1477, 2005.

106. CHAUDHARY D.S., VIGNESWARAN S., NGO H.H., et al. Biofilter in water and wastewater treatment. Korean J. Chem. Eng. 20 (6), 1054, 2003.

107. WIK T. Trickling filter and biofilm reactor modelling. Rev. Environ. Sci. Biotechnol. 2 (2-4), 193, 2003.

108. WANG Q.H., ZHANG L., TIAN S., SUN P.T.C., XIE W. A pilot-study on treatment of a waste gas containing butyl acetate, n-butyl alcohol and phenylacetic acid from pharmaceutical factory by bio-trickling filter. Biochem. Eng. J. 37 (1), 42, 2007.

109. DAS A., NAGA R.N. Activated sludge process with MBBR technology at ETP, Ippta J. 23 (2), 135, 2011.

110. ZHANG Y., CHENG Y., YANG C., LUO W., ZENG G., LU L. Performance of system consisting of vertical flow trickling filter and horizontal flow multi-soil-layering reactor for treatment of rural wastewater. Bioresour. Technol. 193, 424, 2015. 
111. PARKER D.S., NEWMAN J.A. New process design procedure for dealing with variable trickling filter effluent suspended solids, J. Environ. Eng. 132 (7), 758, 2006.

112. WIJEYEKOON S., MINO T., SATOH H., et al. Effects of substrate loading rate on biofilm structure. Water Res. 38 (10), 2479, 2004

113. EWIDA K.T., MOKADEM S.M., KAMAL R.M., ALI A.M. Enhancement of Oxygen Transfer Rate in Trickling Filter using Radial Jet Nozzle, Eighth International Water Technology Conference, IWTC8 2004, Alexandria, Egypt. 347, 2004.

114. EWIDA K.T., SAMEH M., KAMAL R.M.,ALI A.M. Effect of distribution nozzles on trickling filter performance. Tenth International Water Technology Conference, IWTC10 2006, Alexandria, Egypt. 1075, 2006.

115. ODD I.L., HELGE K. Efficiency of nitrification in trickling filters using different filter media. Aquacult. Eng. 21 (3), 181, 2000.

116. EDING E.H., KAMSTRAB A., VERRETH J.A.J. Design and operation of nitrifying trickling filters in recirculating aquaculture: A review. Aquacult. Eng. 34 (3), 234, 2006.

117. ALIMAHMOODI M., YERUSHALMI L., MULLIGAN C.N. Development of biofilm on geotextile in a new multi-zone wastewater treatment system for simultaneous removal of $\mathrm{COD}$, nitrogen and phosphorus. Bioresour. Technol. 107, 78, 2012.

118. MAIKEL F., MARTÍN R., ROSA M. Hydrogen sulphide removal from biogas by an anoxic biotrickling filter packed with Pall rings. Chem. Eng. J. 225, 456, 2013.

119. WANG J., SHI H., QIANY. Wastewater treatment in a hybrid biological reactor (HBR): effect of organic loading rate. Process Biochem. 36 (4), 297, 2000.

120. LUO H., HUANG G., FU X., LIU X., ZHENG D., PENG J., ZHANG K., HUANG B., FAN L., CHEN F., SUN X. Waste oyster shell as a kind of active filler to treat the combined wastewater at an estuary. J. Env. Sci. 25 (10), 2047, 2013

121. WU H., YIN Z., QUAN Y., FANG Y., YIN C. Removal of methyl acrylate by ceramic-packed biotrickling filter and their response to bacterial community. Bioresour. Technol. 209, 237, 2016.

122. ALBERTSON O.E. Excess biofilm control by distributorspeed modulation. J. Environ. Eng. 121 (4), 330, 1995.

123. KUMAR R.B., LAKSHMI P.M., SRINIVASA R.D. Bioremediation of Sewage using Specific Microbial consortium and Biogenic Filter materials. Indian. J. Res. 2 (11), 10, 2013.

124. LIU Y.X., YANG T.O., YUAN D.X., WU X.Y. Study of municipal wastewater treatment with oyster shell as biological aerated filter medium. Desalination. 254 (1-3), 149, 2010.

125. NAZ I., SEHER S., PERVEEN I., SAROJ D.P., AHMED S. Physiological activities associated with biofilm growth in attached and suspended growth bioreactors under aerobic and anaerobic conditions. Environ. Technol. 36 (13), 1657, 2015b.

126. YAOMIN J., MARIA C., VEIGA C.K. Removal of methanol from air in a low-pH trickling monolith bioreactor. Process Biochem. 43 (9), 925, 2008.

127. LIU J., LIU J, LI L. Performance of two biofilters with neutral and low $\mathrm{pH}$ treating off-gases. J. Environ. Sci. 20 (12), 1409, 2008
128. LU C., LIN M.R., CHU C. Effects of pH, moisture, and flow pattern on trickle-bed air biofilter performance for BTEX removal. Adv. Environ. Res. 6 (2), 99, 2002.

129. ARNOLD M., REITTU A., VON WRIGHT A., MARTIKAINEN P.J., SUIHKO M.L. Bacterial degradation of styrene in waste gases using a peat filter. Appl. Microbiol. Biotechnol. 48 (6), 738, 1997.

130. SMET E., CHASAYA G., VAN LANGENHOVE H., VERSTRAETE W. The effect of inoculation and the type of carrier material used on the biofiltration of methyl sulphides. App. Microbiol. Biotechnol. 45 (1-2), 293, 1996 .

131. SMET E., VAN LANGENHOVE H., VERSTRAETE W. Long term stability of a biofilter treating dimethyl sulphide. App. Microbiol. Biotechnol. 46 (2), 191, 1996b.

132. SMET E., LANGENHOVE H., PHILIPS G. Dolomite limits acidification of a biofilter degrading dimethyl sulphide. Biodegradation. 10 (6), 399, 1999.

133. ZILLI M., BORGHI A., CONVERTI A. Toluene vapours removal in a laboratory-scale biofilter. App. Microbiol. Biotechnol. 54 (2), 248, 2000.

134. TANG H.M, HWANG S.J., Transient behavior of the biofilters for toluene removal. J. Air Waste Manage. Assoc. 47 (11), 1142, 1997.

135. DELHOMÉNIE M.C., BIBEAU L., BREDIN N., ROY S., BROUSSAU S., BRZEZINSKI R., KUGELMASS J.L., HEITZ M. Biofiltration of air contaminated with toluene on a compost-based bed. Adv. Environ. Res. 6 (3), 239, 2002.

136. KHATOON N., NAZ I., ALI M.I., ALI N., JAMAL A., HAMEED A., AHMED S. Bacterial succession and degradative changes by biofilm on plastic medium for wastewater treatment. J. Basic Microbiol. 54 (7), 739, 2014.

137. MAUREEN K., RONALD C.S. Algal biofilm based technology for wastewater treatment. Algal Res. 5, 231, 2014.

138. BOHN H. Considering biofiltration for decontaminating gases. Chem. Eng. Prog. 88 (4), 34, 1992.

139. KHATOON N., NAZ I., ALI M.I., ALI N., JAMAL A., HAMEED A., AHMED S. Bacterial succession and degradative changes by biofilm on plastic medium for wastewater treatment. J. Basic Microbiol. 54 (7), 739, 2014.

140. DORADO A.D., BAQUERIZO G., MAESTRE J.P., Gamisans X., Gabriel D., Lafuente J. Modeling of a bacterial and fungal biofilter applied to toluene abatement: kinetic parameters estimation and model validation. Chem. Eng. J. 140 (1-3), 52, 2008.

141. VASILIADOU I.A., PAVLOU S., VAYENAS D.V. Dynamics of a chemostat with three competitive hydrogen oxidizing denitrifying microbial populations and their efficiency for denitrification. Ecologi. Model. 220 (8), 1169, 2009.

142. MUDLIAR S., GIRI B., PADOLEY K., SATPUTE D., DIXIT R., BHATT P., PANDEY R., JUWARKAR A., VAIDYA A. Bioreactors for treatment of VOCs and odours-A review. J. Environ. Manage. 91 (5), 1039, 2010.

143. ZIELIŃSKI M., ZIELIŃSKA M., DĘBOWSKI M. Application of microwave radiation to biofilm heating during wastewater treatment in trickling filters. Bioresour. Technol. 127, 223, 2013. 